\title{
Methodology for the Tariff Formation in Railway Freight Transport
}

\author{
Anna Dolinayová \\ University of Žilina \\ Faculty of Operation and Economics of \\ Transport and Communications \\ Department of Railway Transport \\ Slovak Republic \\ e-mail: anna.dolinayova@fpedas.uniza.sk \\ Vladislav Zitrický \\ University of Žilina \\ Faculty of Operation and Economics of \\ Transport and Communications \\ Department of Railway Transport \\ Slovak Republic \\ e-mail: vladislav.zitricky@fpedas.uniza.sk
}

\author{
Zdeněk Hřebíček \\ Institute of Technology and Business in České \\ Budějovice \\ Faculty of Technology \\ Department of Transport and Logistics \\ Czech Republic
}

DOI 10.17818/NM/2018/4SI.25

UDK 656.23.03

Professional paper

Paper accepted: 28. 8. 2018.

\section{Summary}

Tariff policy outline and the formation of prices for services in freight transport currently lie in the competencies of individual carriers. Price formation in freight transport is fully liberalized and it has contributed mainly to a fair competition and a more effective acquisition activity of railway undertakings. In EU countries, tariffs in railway freight transport are still important today and are applicable in the form of commercial tariffs for individual railway carriers. The aim of this paper is to propose a methodology for the tariff formation in railway freight transport, taking into account the specific technical and technological requirements for transport and costs. The proposed methodology represents the scientific procedures for the efficient design of tariffs for rail freight. The scientific methods used in the methodology are focused on demand analysis, identification of the vehicle fleet, determination of employees, technology of individual shipments, cost calculation and calculation of rates, establishment of price-lists and setting the price of transportation.

\section{INTRODUCTION}

Tariff is a rule of law which sets detailed transport conditions, rates for carriage and travel costs calculation, and reimbursements for side actions. In present terminology it conveys the meaning of an announced list of prices and conditions for using these prices. Some prices in freight transport are currently set according to tariffs.

The arrival of new carriers in freight transport has also been identified as an innovation, investment, improved quality of services, and greater technological and organizational modernisation. On the other hand it has enabled customers to choose from more transport service providers, which stimulates the relation between the quality and price.

Tariffs are to provide customers with clear overview of charges and tariff conditions for specific types of transportation, and concurrently, they should provide for a possibility to decide on a carrier eventually implementing the shipping based on the offered price. The tariff can also be an outcome of a contract between the carrier and the customer in case of regular shipping of a certain commodity or in case of regularity on specific lines, or in case of specifically defined transported volumes. This is also one of the reasons why the tariffs did not lose their importance and find their application also in the environment of the Slovak Republic [1].

Carriers can set their tariffs on the basis of their costs as well as based on individual types of transportation. The benefit of a tariff derives from the fact that the carrier can propose tariff distances/tariff bands and their ranges, and within the individual charges (a price for transportation /shipping) the carrier can consider his risks connected with implementation of specific transportation (transport- and transportationrelated, economic as well as financial), which are necessary for establishing the tariff itself.

The use of a tariff is appropriate for repeated shipments, for specific lines, for selected commodities and also for certain means of transport. The tariff benefit comes from its simplicity, since the customer is able to determine the price for transportation based on a specific procedure. Customers acquainted with the established tariff do not need the carrier to provide them with calculation of prices for individual shipments. Should any of the cost components change, the shipping price calculation or establishment of an alternative tariff is considerably simpler if such establishment occurs [1]. 


\section{PRICING FOR THE PROVISION OF TRANSPORT SERVICES IN THE SLOVAK REPUBLIC}

Railway freight transport charge (i.e. a price for transport service provision) is formed in such a way so carriers can sustain a cost and price competitiveness when compared to other competing transport types. Prices in freight transport are mostly provided as contractual prices, when such a price is affected by two main factors: volume of transports and (financial) reliability of a customer. Some prices provided in railway transport are offered prices and are published in tariffs [2-3]. In the Slovak Republic the offered prices (i.e. a possibility to negotiate a discount) in a tariff are provided by one carrier only - state-owned railway carrier ZSSK Cargo, a.s. In the structure of provided prices $90 \%$ are contractual prices and the remaining $10 \%$ are prices provided in a tariff. Private carriers in freight transport provide their customers with prices based on an individual calculation, in other words contractual prices after fulfilling some conditions of the carrier. Recently, the interest of private carriers in creating custom tariffs has been growing; custom tariffs will be a big contribution in communication between a carrier and a customer [4].

\section{METHODOLOGY FOR THE TARIFF FORMATION}

Every carrier aims at creating such a structure of a tariff policy, including tariff instruments and measures, which would represent a prerequisite for further continuous growth of transportation performances, for increasing the economic efficiency, for improving the quality of delivered services, for increasing the market share, and last but not least, for meeting the needs of customers. Identification of tariff measures in the freight transport has a positive impact on reduced costs of specific shipments, on elimination of risks and thereby also on the increased efficiency [5].

\subsection{Identification of the commodity transportation demand}

An effective concept of a tariff policy, or possibly a flawless elaboration of a tariff by a carrier necessitates understanding of the past and expected future demand of individual transportations.

\section{Demand analysis}

An accurate identification of individual transportation demands in respect of different commodities represents the basis for assessing the general economic situation of the carrier and concurrently for an effective setting of prices in the given tariffs. In railway undertakings the overall demand over the past period can be ascertained relatively easily based on the data from the company economic information systems.

One of the most essential steps in establishing a commercial tariff in the rail freight transport is to define the carrier transportation demand. The carrier transportation demand can be defined as follows:

quantity of transported goods in tons, possibly number of wagon shipments (wagons, groups, unit trains),

as a transportation performance in net tonne kilometers.

In order to establish a tariff it is necessary not only to understand the overall demand of the past period but also the demand for transportation of individual commodities, on the relevant transportation lines, or possibly demand broken down by transportation regimes (import, export, transit, inland transportation). The necessary data can be ascertained from transportation documents (bill of lading), which contain all the essential information related to the transportation demand of a carrier (the type of the transported commodity, total weight of the transported commodity and the transportation line). Individual bills of lading are transposed (the data from the paper bill of lading are entered - retyped in the computer) to the information system of a carrier, the data are processed in an electronic bill of lading and consequently all the significant data are assessed and incorporated in the economic and information databases of the carrier [7].

\section{Customer analysis (potential and contract customers)}

In establishing the tariff in the rail freight transport it is important to consider the customer group for which the tariff is designated. In this case the carrier must differentiate two categories of customers, namely: contract customers and potential customers. In the follow-up in designing the tariff policy, or in determining individual rates in the tariff the carrier must take into account if the tariff is designed only for a specific contract customer /group of customers, who have their transportation volumes contractually established (in tons, wagons, trains), or if it is a tariff, which will be designed for all the customers of the carrier, be that contracted ones or potential ones, or possibly irregular customers. For effective setting of prices in the tariff designed for a specific customer with a contracted volume, the prices are mostly determined as implemented fixed prices (the resulting price reflects the agreed regularity of transportation as well as volume) [7]. In case of tariffs designed for all the customer groups (contract/ irregular/potential) the prices are mostly established as offer prices, i.e. upon meeting conditions of the carrier (usually the goods volume) the offer price can be decreased. The decrease depends on the conditions of the carrier, which can be specified in the tariff itself, or agreed individually with every customer.

\subsection{Identification of the vehicle fleet}

In the following section, the identification of Rail Wagons and Locomotives is processed.

\section{Set-up of rail wagons}

The choice of an appropriate means of transport according to the type of transported commodity is a significant element, which is a factor that determines and subjects the effective establishment of the tariff and at the same time ensures a good quality shipping service. The criterion of an optimal selection of a wagon is its suitability for transportation of specific goods, used transportation route, meeting of the weight standards as well as train length etc. The selection should always be implemented in such a way as to meet the shipper's requirements, but also the requirements of the carrier. The selection of means of transport is also subject to technical characteristics of the vehicle as well as the way of loading/ unloading. The suitability/unsuitability of means of transport can be determined on the basis of analyses of indicators related to transportation specifications of individual vehicles.

The transportation specifications of means of transport - rail wagons is a quantitative as well as qualitative expression of their capacity to safely transport a load from the place of dispatch 
to the place of destination and it is determined especially by the structure of individual wagons as well as by their usage and composition of the wagons fleet as well as the type of the transported cargo. The transportation specifications indicators can be classified in three groups: 1 - Baseline indicators of the wagon loading capacity, 2 - relevant indicators of the transportation specifications, 3 - comprehensive indicators of the wagons fleet utilization. The selection of an appropriate means of transport for a specific commodity can be ensured by calculations of selected indicators of the transportation specifications [8].

\section{Set-up of locomotives}

The selection of the locomotive must take into account the technical specifications of the rail tracks on different lines, first of all the type of traction, gradient and direction aspects, and last but not least, load limit of the relevant locomotive in respect to a specific track. In selecting the locomotive it is necessary that the selected traction vehicle meets the legislative requirements concerning the used railway infrastructure, which means that the locomotive must dispose with an applicable operating permit.

\section{Determining the number of locomotives and wagons}

Determining the number of locomotives and wagons means calculating the number of locomotives and wagons needed on the one hand, and on the other hand to decide on rent or ownership of wagons and locomotives.

The number of needed locomotives and wagons depends on the requirements of customers and technological transport processes. Based on this, carriers must plan a preliminary number of trains per day or per week. Then they create a simplified time plan for each relation. This plan is different for logistic trains (with periodical departures) and other trains. Based on the plan, it can be created while wagons and locomotives are running. It must consider the total technological time in the case of determining the number of wagons (wagons must be in the station, industrial siding or terminal during loading/unloading time) and efficient utilization of locomotives [9].

A universal method for determining how many wagons and locomotives are running does not exist because it depends on many factors such as type of wagon (special/universal), the technical parameters of locomotives, track conditions etc. It is a more difficult task in rail freight transport compared with rail passenger transport because the preliminary and real time table is not periodical and passenger trains are preferred. It is a problem mainly of a track with insufficient capacity [9-10]. Efficient running of wagons and locomotives can be achieved using simulation methods.

\section{Decision making about rent or ownership vehicle park}

Decision making on the rent or ownership of wagons and locomotives must be based on economic effectiveness. It is necessary to compare rent with total locomotive or wagon costs in the same period. Locomotive costs may be made according to the following equation (1):

$$
\emptyset C_{l}=D+\emptyset C_{r, m}+C_{i}+\emptyset C_{e r}
$$

where:

$\varnothing C_{1}$ - total annual locomotive costs,

$D$ - depreciation of locomotive,

$\varnothing C_{r, m}$ - average annual cost for repair and maintenance

$C_{i}$ - annual costs for insurance

$\varnothing C_{e r}$ - average annual costs for extraordinary repair.

Annual costs for repairs consider all costs for regular maintenance. Repairs and maintenance candepend on the time or running of a locomotive. It is necessary to calculate the number of each repair and maintenance during the economic life (e.g. small, medium, main repair of the locomotive). The average annual cost for repair and maintenance is a ratio between multiplying individual repair/maintenance and their costs and the economic life of a locomotive.

Costs for extraordinary repair occur in the event of an accident or damage of a locomotive. The preliminary calculation can determine such things as percentage of average annual costs for repair and maintenance by analysing accidents and damage to a locomotive in the previous period.

Wagon costs are calculated analogous to locomotive costs. Both locomotive costs and wagon costs must be calculated for each type of wagon and locomotive. The result of this decision can be a combination of rent and ownership of wagons and locomotives (e.g. the company can own the electric locomotives and rent the diesel locomotives).

\subsection{Determination of employees}

Determination of personnel is different for locomotives and train crews and other staff (transport supervisors, administrative employees, managers etc.). In the case of other employees their number and qualification depend on transport performance, ways of managing the business etc. The cost for these employees are indirect costs, therefore we do not include them.

The basis for determining a locomotive crew is the running of locomotives. On this basis drawing the plan of the staff roster is needed. This plan must be created in compliance with all legal standards regarding employees. It is important to define working time and staff roster [11-12].

\section{Working time}

Scheduling working time should be adjusted by the staff roster so that, on average, for a regular period, the staff roster corresponds to the designated Weekly Working Time Fund.

Working time includes: performed work, performed preparatory work, overhead journeys, compulsory training, periodic and extraordinary examinations, assessment of health and psychological fitness and lunch breaks.

Preparatory work is a work related to uploading and downloading the work shift and other work related to the performance of work tasks (performance of work) before, after or in a turn of labour.

For locomotive crews the staff roster norm is usually used. This is the number of hours in the relevant month resulting from the workflow schedule of the staff roster, processed according to the set Weekly Working Time Fund. The time of turn norm must correspond to the conversion of the Annual Working Time Fund.

Working time must consider every provision of the statute in the field of labour law, such as the norm of working time, measures in the field of night work (maximum of working night 
Table 1 Concept of a staff roster - regular star times

\begin{tabular}{|c|c|c|c|c|c|c|c|c|c|c|c|c|c|c|}
\hline \multirow{3}{*}{ Employee } & \multicolumn{14}{|c|}{ First week } \\
\hline & \multicolumn{2}{|c|}{ Monday } & \multicolumn{2}{|c|}{ Tuesday } & \multicolumn{2}{|c|}{ Wednesday } & \multicolumn{2}{|c|}{ Thursday } & \multicolumn{2}{|c|}{ Friday } & \multicolumn{2}{|c|}{ Saturday } & \multicolumn{2}{|c|}{ Sunday } \\
\hline & $\begin{array}{l}12 \\
\text { hours }\end{array}$ & $\begin{array}{l}12 \\
\text { hours }\end{array}$ & $\begin{array}{l}12 \\
\text { hours }\end{array}$ & $\begin{array}{l}12 \\
\text { hours }\end{array}$ & $\begin{array}{l}12 \\
\text { hours }\end{array}$ & $\begin{array}{l}12 \\
\text { hours }\end{array}$ & $\begin{array}{l}12 \\
\text { hours }\end{array}$ & $\begin{array}{l}12 \\
\text { hours }\end{array}$ & $\begin{array}{l}12 \\
\text { hours }\end{array}$ & $\begin{array}{l}12 \\
\text { hours }\end{array}$ & $\begin{array}{l}12 \\
\text { hours }\end{array}$ & $\begin{array}{l}12 \\
\text { hours }\end{array}$ & $\begin{array}{l}12 \\
\text { hours }\end{array}$ & $\begin{array}{l}12 \\
\text { hours }\end{array}$ \\
\hline \multicolumn{15}{|l|}{$\begin{array}{l}\text { 1. engine } \\
\text { driver }\end{array}$} \\
\hline \multicolumn{15}{|l|}{$\begin{array}{l}\text { 2. engine } \\
\text { driver }\end{array}$} \\
\hline \multicolumn{15}{|l|}{$\begin{array}{l}\text { 3. engine } \\
\text { driver }\end{array}$} \\
\hline & \multicolumn{14}{|c|}{ Second week } \\
\hline & \multicolumn{2}{|c|}{ Monday } & \multicolumn{2}{|c|}{ Tuesday } & \multicolumn{2}{|c|}{ Wednesday } & \multicolumn{2}{|c|}{ Thursday } & \multicolumn{2}{|c|}{ Friday } & \multicolumn{2}{|c|}{ Saturday } & \multicolumn{2}{|c|}{ Sunday } \\
\hline & $\begin{array}{l}12 \\
\text { hours }\end{array}$ & $\begin{array}{l}12 \\
\text { hours }\end{array}$ & $\begin{array}{l}12 \\
\text { hours }\end{array}$ & $\begin{array}{l}12 \\
\text { hours }\end{array}$ & $\begin{array}{l}12 \\
\text { hours }\end{array}$ & $\begin{array}{l}12 \\
\text { hours }\end{array}$ & $\begin{array}{l}12 \\
\text { hours }\end{array}$ & $\begin{array}{l}12 \\
\text { hours }\end{array}$ & $\begin{array}{l}12 \\
\text { hours }\end{array}$ & $\begin{array}{l}12 \\
\text { hours }\end{array}$ & $\begin{array}{l}12 \\
\text { hours }\end{array}$ & $\begin{array}{l}12 \\
\text { hours }\end{array}$ & $\begin{array}{l}12 \\
\text { hours }\end{array}$ & $\begin{array}{l}12 \\
\text { hours }\end{array}$ \\
\hline \multicolumn{15}{|l|}{$\begin{array}{l}\text { 1. engine } \\
\text { driver }\end{array}$} \\
\hline \multicolumn{15}{|l|}{$\begin{array}{l}\text { 2. engine } \\
\text { driver }\end{array}$} \\
\hline \multicolumn{15}{|l|}{$\begin{array}{l}\text { 3. engine } \\
\text { driver }\end{array}$} \\
\hline wor & ing time & & relax & time & & & & & & & & & & \\
\hline
\end{tabular}

Source: authors

time, the number of night staff roster per week etc.), overtime, holidays etc. in every country that the locomotive crew rides in.

\section{Creation of the preliminary staff roster}

The preliminary staff roster of a locomotive crew should be created by preliminary locomotives running and general interest with respect to effectiveness of transport, security and legitimate interests of employees. Table 1 describes the concept of a staff roster for continuous operating.

As can be seen in table 1, the staff roster repeats every four days. The staff roster thus designed allows not only to keep obligatory relax time but also to change the working time on the weekend for each employee (the staff roster on the weekend repeats every four weeks). The employer must consider five engine drivers in this case because the average weekly time of each engine driver is 42 hours and working time includes other activities described in the previous chapter.

Creation of a staff roster is different for employees with regular start times than for employees with irregular start times. Rail freight transport locomotive crews nearly always have irregular work start times. The staff roster must be created by the preliminary driving time of the train and other necessary processes, but the staff roster for locomotive crews with regular work start times can be used as the basis for creating working time and compulsory relaxation.

\subsection{Technology of individual shipments}

The technology of wagon consignments processing in case of specific types of transportation can be decisive for setting of the total price for transportation given in the tariff. Demands of the technological procedures have an impact on the costs increasing of the carrier, for example in case of shipments under special transportation conditions and therefore an accurate identification of all the activities related to trains processing. It is recommended that the graphical representation of individual actions related to processing of an originating or a terminating train is implemented using the Gantt Chart (a kind of bar chart
- graphically illustrating sequence of actions in time), which illustrates graphically individual activities of the carrier in sequence, their time information (their duration impacts the costs of the carrier), standard limit of the activity, the employee implementing the activity (different employee cost rates), parallel activities and the overall time. Every implemented activity of the carrier can be appraised by means of unit costs and consequently it is possible to set more accurate price for a shipment, or possibly a part of the price for the shipment called the "price for consignment dispatching". The price for the consignment dispatching is a total sum of actions carried out in respect of every single consignment in the dispatching station as well as terminating station regardless of the transportation distance.

\subsection{Cost calculation}

Cost calculation is the basis for determining a tariff or price on agreement. The cost calculation must take into consideration the total cost for every transport relation and every other service that a carrier plans to provide. Calculation methods are different for calculating transport costs and costs of additional services.

Transport costs calculation

Transport costs calculation comprises all direct and indirect costs. Direct costs include transport sources (traction oil consumption, traction electricity consumption), every cost of employees directly participating in transport performances (wages, social costs, benefits, compensation etc.), depreciation of the vehicle, repair and maintenance of the vehicle, rail infrastructure charges and other direct costs. Direct costs can be calculated using a type of calculation formula or analytical formulas which calculate costs by multiplying performed transport output and the rate of transport output for every item in the calculation. A detailed description of this method is listed in the literature [13].

The result of the transport calculation costs should be not only knowledge about the total unit costs but the changes of costs in the case of whatever transport parameters. Table 2 shows the model to calculate the unit transport cost for a train. 
Table 2 Model to calculate the unit transport cost

\begin{tabular}{|c|c|c|c|c|}
\hline Capacity utilization of wagons & $30 \%$ & $40 \%$ & $\ldots$ & $100 \%$ \\
\hline Number of wagons in a train & nett/gross tonnes & nett/gross tonnes & $\ldots$ & nett/gross tonnes \\
\hline \multicolumn{5}{|l|}{10} \\
\hline \multicolumn{5}{|l|}{11} \\
\hline \multicolumn{5}{|l|}{12} \\
\hline \multicolumn{5}{|l|}{13} \\
\hline & & & & \\
\hline
\end{tabular}

Source: authors

This model can be used if the company uses a relational tariff. If the company uses a zonal tariff, the transport cost must be calculated for an individual zone. In this case the model (described in the previous table) changed, thus the first column will contain an individual zone and a new table must be calculated for a different number of wagons in a train. Calculating the cost by this model is relatively simple and does not require special economic software. Data from intra-plant accounting and MS Excel is sufficient.

\section{Cost calculation of additional services}

The company can provide different additional services to provide complex services to customers. Some can be provided by purchasing from a supplier and some are provided by the company itself. If the services are provided by outsourcing, the costs for these services are purchase price. If a company provides services itself, it must calculate the unit cost for every service [13].

A general formula for this cost does not exist because technological processes are different for every additional service. Unit costs for additional service wagon weighing can be calculated according to the following equation (2):

$$
U C_{w w}=\frac{A C_{w}+\% A C_{d}+\% A C_{s}+\% A C_{e}+\% A C_{o}+\% A C_{a o}}{\sum W_{w}}
$$

where:

$U C_{w w}$ - unit total costs for a wagons weighing,

$A C_{w}$ - annual cost of a weighbridge,

$A C_{s}$ - annual costs of a documentation,

$A C_{s}$ - annual costs of a shunting,

$A C_{e}-$ annual costs of the employees, which weight wagons,

$A C_{0}$ - annual costs for an office and other spaces,

$A C_{a o}$ - annual cost of an administration overhead,

$W_{w}$ - average number of weighted wagons per year.

The costs of a weighbridge are the direct cost; therefore, they are allocated from intra-plant accounting. Another cost item is common cost and it is needed to allocate these costs using the same calculation method. This is more often used for full-absorption costing analogous to cost calculation for a train. In the same principle, unit costs for other services can be calculated.

\subsection{Calculation of rates, establishment of price-lists and setting of price for transportation}

For the rates calculation it is important to know the transportation costs analysis (mentioned above). The costs represent one of the most significant factors impacting the rate (calculation of costs under different vehicle capacity usage, under different numbers of wagons dispatched for transportation, calculation of costs reflecting the type of the vehicle) [14]. Other factors having impact on the resultant rate include the following: amount of the reasonable profit, regularity of shipments, agreed-on volume, risks occurrence affecting the carrier, and last but not least also the requirements of the customer.

The rate is a price for unit of transportation or unit of transportation performance. The rate consists of two components: the rate base (actions that are implemented with every consignment, regardless of the distance and related costs) and the rate increment (it is a part of the rate, which is dependent on the covered distance - costs for infrastructure, costs for utilities/traction rolling stock..).

Setting of the rate in tariffs can be different:

Distance-related rates:

- kilometre tariff (rate/km) - rather not used in the freight transport

- costs calculation for each kilometre individually with regard to different utilization of the vehicle capacity and each kilometre, e.g. from 1 up to $500 \mathrm{~km}$ has its rate

- band tariff - frequently used type of price-lists in the freight transport

- calculation of costs for each tariff band individually, a decisive point for specification of costs is the centre of the tariff band, or the upper/lower limit of the band and each band has its rate, bands can be evenly/unevenly divided

- line tariff - most frequently used for contract customers, contracted shipment on a specific line (path)

- rate determined for a specific line, e.g. Bratislava - Žilina

- myriametric tariff - medium-frequently used type of pricelists

- principle of rate determination same as in the band tariff and the same width of tariff bands within the whole of the price-list

Weight tariffs - goods weight indicator

- Rates depending only on the tariff weight

- R (rate) x m (weight)

Group tariffs - frequently used for contract customers, e.g. in case of a shipment of one commodity between railway junctions (BA, KE, ZA a ZV)

- rate is determined for a certain group of tariff points

- Performance tariffs - the most frequent tariff type used in the railway freight transport

- rate is determined depending on the distance as well as weight of consignment (tonne $\mathrm{km}$ )

Other rates - depending on the customer requirements 
Table 3 Price-list reflecting the type of the transported commodity

\begin{tabular}{|c|c|c|}
\hline Price-list „,commodity & general shipping conditions & special transport conditions * \\
\hline Tariff distance & Price/1 tonne & Price/1 tonne \\
\hline $1-100$ & $10 €$ & $12 €$ \\
\hline $101-200$ & $20 €$ & $24 €$ \\
\hline $201-300$ & $30 €$ & $36 €$ \\
\hline * dangerous commodity, secial commodity... & & \\
\hline
\end{tabular}

Source: authors

- Rate for a train/group of wagons

For the establishment of price-lists it is possible to combine the previous tariff types and to create one rate, for example a band/performance tariff: different rates for individual bands, which are also dependant on the tariff weight presented for shipping by the customer. When establishing the price-lists it is also important to consider the general tariff applicability (material, territorial as well as temporal). The tariff can contain multiple types of price-lists depending on different factors:

price-list reflecting wagons ownership, or possibly leasing, price-list reflecting the type of the transported commodity: price-list reflecting the type of the vehicle, price-list reflecting the number of wagon axles, price-list reflecting the type of shipping in terms of the territory, pricelist reflecting the material tariff applicability (wagon shipments, empty wagons and ITU) and price-list reflecting unused capacity of the vehicle etc.

\section{Setting the price for shipping (principles for calculation of shipping charges)}

Calculation of the price for shipping (transportation) according to the tariff can be different. In order to simplify the price calculation for the customer, in determining the final price the carrier can derive only from the price-lists (the rates include all the costs for activities incurred by the carrier in implementing the given shipping + all the risks and reasonable profit) or pricelists are only the first step for determining the price and the carrier defines other criteria in the tariff which have an impact on the amount of the charge for shipping (type of the wagon, number of axles, ITU type..). The first method of the price setting is more time demanding and many a time the given rates do not reflect all the value and volume indicators [15].

\subsection{Final tariff}

In terms of the current terminology a tariff means an official price list as well as conditions for using these prices. Under the Act on Prices 18/1996 a tariff is considered as a price. In the rail transport context a tariff is understood as a legal provision, which determines detailed transportation conditions (general as well as detailed tariff conditions), rates for calculation of transportation charges and fees for ancillary activities [16].

In order to set up the final tariff it is important to ensure processing of analyses of individual points of the designed methodology (the cost analysis for individual types of transportation as basic information for determination of the price, the analysis of transportation demand, price lists, requirements of customers ....). In addition to the given points it is important that the final tariff (prescription) meets general principles of the tariff establishment in the freight transport (described in the following point) and that it has a structure, which is perceived by the customer as simple and understandable.

\section{General principles of the tariff establishment in the freight transport}

To make a tariff properly applicable it is important that it meets several principles. The first such principle is the "principle of the tariff validity". This definition of the tariff concept derives from the general concept of the tariff as a legal rule, which is issued for execution of another legal rule, namely the rules of transportation. This implies that the rules of transportation in terms of their contents always represent a superior legal instrument to the tariff, which, as a rule issued for its implementation, must not exceed the framework defined for its contents by the transportation rules [17]. The tariff should also be somehow publicized, the principle of public access, preferably already prior to its effectiveness the relevant customers should get acquainted with the conditions and prices set in the tariff.

The other principles, which should be met, include the following:

Principle of clarity and simplicity,

Principle of recovery of costs for executed performance

Principle of equity subject to meeting the conditions set out in the tariff.

The final freight tariff should also reflect other principles, which can be defined as principles of pricing (the price policy of the carrier):

- The price for a shipping performance should be set on the basis of the costs analysis of the carrier as well as his reasonable profit,

- should cover the amount of his proper costs,

- should reflect the level of demand and offer,

- should reflect the level of technological progress,

- in setting the price it should derive from the estimated profit rate,

- Prices in the tariff should not show as being dumped,

- The level of the tariff price must flexibly react to the inflation development in the national economy to avoid price deformation,

- Prices defined in the tariffs for contract customers should reflect regularity of shipments as well as agreed-on volume, - Charges for transport should be economically reflected in the efficient pricing.

\section{Basic tariff structure in the rail freight transport}

The tariff structure itself has not been prescribed, nor set out by any regulation in the Slovak Republic, and its set-up falls within the carrier's discretion [18]. The lay out of the tariff can be different (sections, instalments, parts, units, articles, 
numbering ...). For the sake of the methodology design the following part describes a general model of the tariff structure in the freight transport $[19,20]$ :

- Title page - basic information for easy identification of the customer:

- tariff designation, tariff No. as well as acronym for the lading bill inscription, name of the carrier issuing the tariff, statistical classification of products No. under the Decree as well as date of the Tariff effectiveness,

- Tariff contents - summary of all that forms the tariff:

- Tariff provisions, price lists, supporting tables, supplementary charges ...,

explanatory notes to acronyms used in the tariff and setting out the basic definitions,

Introductory provisions of the tariff / preamble - general tariff characteristics:

- Tariff descriptions, who issues the tariff, for whom it is designed, purpose of the tariff, publication of the tariff, types of prices, tariff effectiveness, value added tax, changes in the tariff ....,

- General tariff provisions - basic provisions on setting the price for transportation according to the tariff:

- scope of the tariff applicability, transportation routes line tariffs, tariff distances - band-/distance-related tariff, tariff currency, principles for calculation of transportation charges, factors having impact on the transportation charges, tariff weight as price calculation criterion, minimal tariff weights/weight levels, transportation charges by material applicability - wagon shipments, empty wagons [17],

- Special tariff provisions - detailed provisions related to transportation specificities:

- empty wagons as means of transport, long indivisible objects, extraordinary shipments, dangerous goods, wagons added to the consignment for technical reasons, train unit/group of wagons, wide track gauge,...,

Tables of charges/price lists - specific prices and price conditions:

- Prices given by means of rates - band- and distancerelated tariffs and prices given as calculated transportation charges - line tariffs, ,

- Supporting tables for calculation of transportation charges - for final calculation of the price for transportation, in case it depends on several criteria (in addition to the distance and weight):

- Table of grid coefficients (intermodal transport units), weight levels (unused capacity of means of transport), coefficients for price increase/decrease and rates for specific lines.

- Basic supplementary fees - according to regular customer requirements: Fee designation, fee content, fee price.

Other supplementary fees.

In general, the word "tariff" contains two basic conceptual features, namely the list of prices, and specifically the fact that it was published. Both of these features should be understood in their interconnection in such a way, that it is a list of prices whose general applicability derives from the fact that it was made officially public, i.e. publicized or possibly published. The effect is that the tariff has the nature of a binding legal rule.

\section{CONCLUSION}

Cost analysis is important part for the creation of tariff or price on agreement. In the case when the company establishes a new service in the transport market, the costs calculation is the basis for setting the price. If the company offers services which exist on the transport market the target of cost analysis is validated if the price (determined by the market) generates a profit. Besides demand which determines the maximum price and the costs which determine the minimum acceptable price it is important to be acquainted with the competitive prices, expected changes, rate of risk etc. All these factors influence profit (on condition that the demand is elastic) and competitiveness of company in the long run.

\section{Acknowledgement}

The paper was supported by the KEGA Agency, Grant No 010ŽU$4 / 2017$ "New methods of teaching quality management in the study program Railway transport with a focus on optimization of extraordinary events in terms of customer orientation" at Faculty of Operations and Economics of Transport and Communication, University of Žilina, Slovakia.

\section{REFERENCES}

[1] Hokstok, C. Application framework of value stream costing (VSC) for supporting rail infrastructure controlling. Logi - Scientific Journal on Transport and Logistics, 2013, Vol. 4, No. 1, pp. 63-80. ISSN 1804-3216.

[2] Nedeliaková, E., Harmanová, D., Panák, M., Kudláč, Š. Selected problems of risk management in the company of railway infrastructure manager In: Transport means 2016: proceedings of the 20th international scientific conference, Kaunas University of Technology, 2016. ISSN 1822-296X.

[3] Buková, B., Brumerčíková, E., Kondek P. Impact of population development and employment on the transport performance in the EU. ICTTE 2016 international conference on Traffic and transport engineering, Belgrade, Serbia, 2016. ISBN 978-86-916153-3-8.

[4] Jarocka, M., Ryciuk, U. Pricing in the Railway Transport. In: 9th Internationa Scientific Conference - Business and Management 2016. Book Series: Business and Management-Spausdinta, 2016, Vilnius Gediminas Technical University, Vilniius, Lithuania. https://doi.org/10.3846/bm.2016.76

[5] Stopka, O. Chovancová, M., Ližbetin, J., Klapita, V. Proposal for optimization of the inventory level using the appropriate method for its procurement. Naše more: Our sea: znanstveno-stručni časopis za more i pomorstvo, 2016, Vol. 63, No. 3. ISSN 0469-6255.

[6] Dolinayová, A., Nedeliaková, E., Brumerčíková, E. Economics of rail transport: management of railway undertakings. University of Zilina, 2016. ISBN 978-80-554-1283-2.

[7] Varjan, P., Rovňaníková, D., Poliak, M. Examining changes in GDP on the demand for road freight ransport. In: Procedia Engineering, 2017, Vol. 192, pp. 911-916. ISSN 1877-7058.

[8] Masek, J., Kendra, M., Camaj, J. Model of the Transport Capacity of the Train and Railway Track Based on Used Types of Wagons. In: Transport Means 2016. Proceedings of the International Conference, 2016, Juodkrante, Kaunas Univ Technology, Lithuania, pp. 584-588. ISSN 1822-296X.

[9] Gasparik, J., Abramovic, B., Halas, M. New Graphical Approach to Railway Infrastructure Capacity Analysis. Promet-Traffic \& Transportation, 2015, Vol. 27, Issue 4, pp. 283-290. https://doi.org/10.7307/ptt.v27i4.1701

[10] Marinov M, Sahin I, Ricci S, Vasic-Franklin G. Railway operations, timetabling and control. Research in Transportation Economics, 2013, Vol. 41, Issue 1, pp. 59-75. DOI: org/10.1016/j.retrec.2012.10.003.

[11] Olexova, C., Mesaros, P., Basistovs, A. Priorities of human resources management in knowledge economy. Business Trends - scientific periodic of Faculty of economic ZČU in Plzen, 2011, Vol. 1, pp. 26-30.

[12] Kampf, R., Hitka, M., Potkány, M. Interannual differences in employee motivation in manufacturing enterprises in Slovakia. University of Zilina. Communications, 2014, Vol. 16, No. 4, pp. 98-102. ISSN 1335-4205.

[13] Dolinayova, A., Loch, M., Kanis, J. Modelling the influence of wagon technical parameters on variable costs in rail freight transport. Research in Transportation Economics, 2015, Vol. 54, pp. 33-40. https://doi. org/10.1016/j.retrec.2015.10.023

[14] Kampf, R., Lorincova, S. Hitka, M., Stopka, O. Generational Differences in the Perception of Corporate Culture in European Transport Enterprises. Sustainability, 2017, Vol. 9, Issue 9. https://doi.org/10.3390/su9091561 
[15] Chovancova, M., Klapita, V. Modeling the Supply Process Using the Application of Selected Methods of Operational Analysis. Open Engineering, 2017, Vol. 7, Issue 1, pp. 50-54. https://doi.org/10.1515/eng2017-0009

[16] Abramović, B., Zitrický, V., Biškup, V. Organisation of railway freight transport: case study CIM/SMGS between Slovakia and Ukraine. European transport research review, 2016, Vol. 8, Issue 4, art. No. 27. ISSN 1867-0717

[17] Kampf, R., Gašparík, J., Kudláčková, N. Application of different forms of transport in relation to the process of transport user value creation. Periodica Polytechnica Transportation Engineering, 2012, Vol. 40, No. 2 pp. 71-75. ISSN 0303-7800.
[18] Široký, J., M. Slivoně, V. Cempírek. Single and multiple allocation in huband-spoke networks and the transportation cost comparison. Logi Scientific Journal on Transport and Logistics, 2010, Vol. 1, No. 2, pp. 52-62. ISSN 1804-3216.

[19] Islam, D.M.Z., Zunder, T.H., Jackson, R., Nesterova, N., Burgess, A. The potential of alternative rail freight transport corridors between central Europe and China. Transport Problems, 2013, Vol. 8, No. 4, pp. 45-57. ISSN 1896-0596.

[20] Bokor, Z. Cost calculation in complex transport systems. Logi - Scientific Journal on Transport and Logistics, 2013, Vol. 4, No. 1, pp. 5-22. ISSN 18043216. 